\title{
A METHOD OF CALCULATING FILTRATION RATE OF AN INFILTRATION WATER INTAKE IN KURSK REGION
}

\author{
Vladimir Viktorovich Bredihin* \\ Southwest State University, Kursk, Russia \\ Alexander Anatolyevich Akulshin \\ Southwest State University, Kursk, Russia \\ Natalia Vladimirovna Bredihina \\ Southwest State University, Kursk, Russia \\ Valeria Sergeevna Pereverzeva \\ Southwest State University, Kursk, Russia
}

The paper describes a method to calculate filtration rates that can be used to find equipment with best performance considering the well specific features. The method is presented by using an example of an infiltration intake in Kursk (Black Soil Region, Russia). The paper contains the formula to calculate filtration rates of various grounds for different well types located in different hydrological and hydrogeological areas. The applied equations are built on Dupuit equations.

Key words: Waterbearing bed, Filtration rate, Well, Ground waters, Dupuit equation

\section{INTRODUCTION}

Geological and economic factors of groundwater exploration and development are determined by hydrologic situation in the groundwater deposit area and engineering conditions of its exploitation such as groundwater occurrence depth, water-bearing rock characteristics, discharge of wells, water level drop in the process of their exploitation, etc.

Filtration flow rate $Q$ is related through its crosssection area $\omega$ with head gradient $\mathrm{i}$ by linear dependence:

$\mathrm{Q}=\mathrm{K} \dot{\omega} \mathrm{i}$

Having introduced the notion of filtration $V$ rate as the flow rate of water running through the flow cross-section unit area we can find:

$$
\vartheta=\frac{Q}{\dot{\omega}}=K_{\dot{\Phi}}
$$

Hence it is possible to find the filtration ratio value as the filtration speed with the head gradient $i=1$. If we study the filtration process in liquids with different fluid dynamic properties, we should apply the notion of permeability ratio, $K_{n}$.

Permeability is the ability of a rock to be pervious for water under pressure.

$$
\mathrm{Q}=\mathrm{F} \cdot \frac{K_{n}}{\mu} \cdot \frac{d P}{\mathrm{dx}}
$$

Where $Q$ - the flow rate of a liquid; $P$ - is the flow cross-section area; $K_{n}$ - permeability ratio; $\mu$ - fluid viscosity; $\mathrm{dP} / \mathrm{dx}$ - barometric gradient.

Permeability is a feature of a porous medium and does not depend on the properties of filtered liquids.

Filtration ratio $K_{F}$, unlike the permeability ratio characterizes the properties of water-permeable rocks depending on the properties of influent liquids. The correlation between the filtration ratio and permeability ratio is expressed by the relationship:

$$
K_{\dot{\phi}}=864 \frac{K_{n} \cdot \gamma_{a}}{\mu},
$$

Where $Y_{a}$ - is water density.

In the system of physical quantities the dimension $\mathrm{Kn}$ is expressed in square centimeters. However a more commonly used unit is darcy $\left(1 \mathrm{~d}=1.02 \cdot 10^{-8} \mathrm{CM}^{2}\right)$. For water the permeability of $1 \mathrm{~d}$ approximately corresponds to the filtration ratio of $1 \mathrm{~m} /$ day.

According to G. Kamensky and some other researchers filtration linear law can be applied not only to fine-grain and coarse-grain sands, 
but also to mixed sand-and-shingle formations with sufficiently practicable accuracy.

\section{THE METHOD OF DETERMINING THE COEFFICIENTS OF THE FILTRATION}

The investigated water intake is located to the north of Kursk (Black Soil Region in Russia) in the flood land of the river Seim. Production water-bearing bed consists of anisomerous silica sands of fluvial sediments and Albian stage sediments. The magnitude of water bed is about 27 $\mathrm{m}$. Prospecting works have shown that the water bed is unconfined. It is located at a depth of 3 to $8 \mathrm{~m}$ below the land surface.

As is known a water intake facility of should be designed and operated taking account such water bed property as its permeability. If the soil permeability decreases, productive water yield also goes down.

In order to find filtration rate of productive water beds we used Dupuit equations (the dependency of water well yield on the parameters of the operating waterbearing bed) $[01,08,09]$. For perfect wells they will look like:

- for the ones supplied from non-confined ground waters:

$$
Q=\pi K_{\Phi} \frac{(2 H-s) s}{\ln \frac{R}{r_{0}}}
$$

- for the ones supplied from confined ground waters

$$
Q=2 \pi K_{\dot{\phi}} m \frac{s}{\ln \frac{R}{r_{0}}}
$$

where $Q$ - is the well yield, $\mathrm{m}^{3} /$ day; $K_{F}$ - filtration rate of the ground of productive waterbearing bed, $\mathrm{m} /$ day; $\mathrm{H}$ - the magnitude of ground waterbearing source, $\mathrm{m} ; \mathrm{m}$ - the magnitude of the artesian aquifer, $\mathrm{m}$; $\mathrm{S}$ - water level drop below its static level in the well, $m$; $R$ - drainage area radius, $\mathrm{m} ; r_{0}$ - well hydraulic area radius, $\mathrm{m}$.

Having processed the ground sampling data obtained from waterbearing beds with subsequent mathematical transformations of the Dupuit equation, we got the following formulas to find the filtration rates for different hydrological and hydrogeological conditions in Kursk [02, 03, 06, 07].

1. To calculate filtration rate of a single imperfect well sunk in a confined finite bed $(\mathrm{L} / \mathrm{m}>0.1)$ we used Dupuit formula the correction for imperfection:

$$
K_{\dot{\Phi}}=\frac{0.366 Q\left(\lg \frac{R_{n}}{r_{0}}+0.217 \xi\right)}{m \cdot S_{0}},
$$

where $R n-$ is drainage area radius, $m ; \xi-$ is the magnitude of filtration resistance considering the well imperfection and is found from the table depending on the relationship between the length of the filtering section ( $\mathrm{I}$ ) to the magnitude of the water bearing bed $(\mathrm{m})$ and the relation of the water bearing bed magnitude to the well radius ( $\mathrm{z}$ ); $\mathrm{S}_{0}$ - water level drop in the well, $\mathrm{m}$.

The reduced drainage area radius is found in the following way:

a) If the well is located close to the watercourse: $R_{n}=2 a$

where $\alpha$ - is the distance between the well and the watercourse, m;

b) if the well is located far from the watercourse:

$$
R_{n}=1.5 \sqrt{a t} \text {, }
$$

where $\mathrm{a}$ - is pressure conductivity factor, $\mathrm{m}^{2} /$ day; $\mathrm{t}$ - extraction time, days.

2. Filtration rate of single imperfect wells sunk in a non-confined finite water bearing bed was calculated by Dupuit formula with correction for imperfection:

$$
K_{\dot{\Phi}}=\frac{0.73 Q\left(\lg \frac{R_{n}}{r_{0}}+0.217 \xi\right)}{(2 H-S) S_{0}}
$$

The notation is the same.

3. During cluster pumping tests of imperfect wells located in a finite reservoir filtration rate was calculated by Dupuit formula with the correction for imperfection.

3.1 With confined waters:

a) the central well rate was calculated by formula 5 , and

b) for two observation wells it was:

$$
K_{\dot{\Phi}}=\frac{0.366 Q\left[\lg \frac{r_{2}}{r_{1}}+0.217\left(\xi_{1}-\xi_{2}\right)\right.}{m\left(S_{1}-S_{2}\right)},
$$

Where $r_{1}, r_{2}$ - are the distances to the first and the second observation wells, $\mathrm{m} ; \xi_{1}, \xi_{2}$ - the values of filtration resistance considering the imperfection of the first and the second observation wells.

3.2 With non-confined waters:

a) the central well rate was calculated by formula

4 , and b) for two observation wells it was: 


$$
K_{\Phi}=\frac{0.73 Q\left[\lg \frac{r_{2}}{r_{1}}+0.217\left(\xi_{1}-\xi_{2}\right)\right.}{\left(2 H-S_{1}-S_{2}\right)\left(S_{1}-S_{2}\right)}
$$

4. For single perfect wells sunk in a confined bed:

$$
K_{\Phi}=\frac{0.366 Q \lg \frac{R_{n}}{r_{0}}}{m S_{0}}
$$

5. For single perfect wells sunk in a non-confined bed:

$$
K_{\Phi}=\frac{0.73 Q \lg \frac{R_{n}}{r_{0}}}{\left(2 H-S_{0}\right) S_{0}}
$$

6. To find the filtration rate of poor wells by using the results of well filling and slug-out tests we Babushkin-Shestakov formula was used $[04,05]$ :

$$
K_{\dot{\Phi}}=\frac{a^{o}}{t} \lg \frac{s_{0}}{s}
$$

where $a^{\circ}$ depends on the location of the filter. Simultaneously with calculating the filtration rate by formulas $7,8,9,10,11$ and 12 filtration rate check calculations were performed considering the results of water level recovery after the end of water extraction. To do it temporal tracing charts were plotted based on time logarithm and filtration rate was calculated by the following formulas:

6.1 For confined waters:

$$
\begin{aligned}
& K_{\phi}=\frac{0.183 Q}{m C}, \\
& C=\frac{S_{2}-S_{1}}{\lg t_{2}-\lg t_{1}},
\end{aligned}
$$

$C$ - is the slope ratio found by the formula:

6.2 For non-confined waters:

$$
\begin{aligned}
& K_{\phi}=\frac{0.366 Q}{C\left(H-\frac{S_{0}}{2}\right)}, \\
& C=\frac{S_{2}\left(2 H-S_{2}\right)-S_{1}\left(2 H-S_{1}\right)}{\lg t_{2}-\lg t_{1}}
\end{aligned}
$$

As the outcome of check calculations about $75 \%$ of the results yielded a visible feedback (the deviation did not exceed $15 \%$ ).

To determine the filtration rate of a recent swampy waterbearing bed the calculations were based on the results of cluster pumping and slug-out tests run in open holes. Filtration rates were calculated by transient motion formulas considering the perfection rate of the wells.

7. To find the filtration rate for cluster perfect wells sunk in a non-confined bed, the following formulas were used:

a) the central well rate was calculated by formula 12; and

b) for two observation wells by the formula:

$$
K_{\Phi}=\frac{0.73 Q \lg \frac{r_{2}}{r_{1}}}{\left(2 H-S_{1}-S_{2}\right)\left(S_{1}-S_{2}\right)},
$$

Filtration rates were generally found by Dupuit formula with Verigin's imperfection correlation data:

8. To find the filtration rate of a single imperfect well located close to a river, the following formulas were used:

a) for non-confinement condition:

$$
K_{\dot{\Phi}}=\frac{0.73 Q\left(\lg \frac{2 b}{r_{0}}+0.217 \xi\right)}{(2 H-S) S},
$$

b) for confined - free-flow conditions:

$$
K_{\Phi}=\frac{0.73 Q\left(\lg \frac{2 b}{r_{0}}+0.217 \xi\right)}{(2 H-m) m-h^{2}},
$$

c) for confined conditions:

$$
K_{\dot{\Phi}}=\frac{0.366 Q\left(\lg \frac{2 b}{r_{0}}+0.217 \xi\right)}{m S}
$$

where in the formula for a confined - free-flow water bearing bed $\mathrm{H}$ - is initial water height measured from its static level and down to the water bed base; $h$ - water height measured from its $d y-$ namic level and down to the water bed base, $\mathrm{m}$; $b$ - the distance between the wells and river, $m$.

\section{CONCLUSION}

The proposed method of finding the filtration rate can help to determine water wells with the most optimal equipment for specific water beds. 


\section{REFERENCES}

1) Belickij, A.S., Dubrovskij, V.V. (1974) Proektirovanie razvedochno-ehkspluatacionnyh skvazhin dlya vodosnabzheniya.

2) Kotlov, V.V. (1968) Otchet o rezul'tatah issledovaniya rezhima podzemnyh vod KMA.

3) Gidroproekt. Rukovodstvo po opredeleniyu koehfficienta fil'tracii vodonosnyh porod metodom opytnoj otkachki P-717-80 (1981).

4) Babushkin, V.D. (1950) Ukazaniya po opredeleniyu koehfficienta fil'tracii pri opytnyh otkachkah iz nesovershennyh skvazhin.

5) Babushkin, V.D. (1958): K metodike opredeleniya pritoka vody k kar'eru, nesovershennomu kotlovanu i shahtnomu kolodcu $\mathrm{v}$ dvuhslojnoj tolshche. Gosgeotekhizdat. Byul. nauch. tekhn. inf. № 5 (17). s. 58-61.

6) Akul'shin, A.A., Kobelev, N.S. (2011): Metody prokachki skvazhin pri peskovanii, Izvestiya YUgo-Zapadnogo gosudarstvennogo universiteta. Seriya Tekhnika i tekhnologii, №8, s.109-112.

7) Akul'shin, A.A., Petrichenko, V.P., Akul'shin, A.A., SHalaj, I.S. (2012): Analiz metodov vosstanovleniya debita vodozabornyh skva- zhin, Izvestiya YUgo-Zapadnogo gosudarstvennogo universiteta. Seriya Tekhnika i tekhnologii, CHast' 2, №2, s.35-38.

8) Akul'shin, A.A., Pereverzeva, V.S., Akul'shin, A.A. (2014): Opredelenie optimal'nyh razmerov konstruktivnyh parametrov provolochnyh fil'trov, Matematika i eyo prilozheniya $v$ sovremennoj nauke i praktike: Sbornik nauchnyh statej IV Mezhdunarodnoj nauchno-prakticheskoj konferencii studentov i aspirantov (16-18 aprelya 2014 goda), s. 90-94.

9) Akul'shin, A.A., Pereverzeva, V.S., Akul'shin, A.A. (2014): Opredelenie optimal'noj skvazhnosti provolochnyh fil'trov $v$ zavisimosti ot parametrov trubchatyh i grunta, Matematika i eyo prilozheniya $v$ sovremennoj nauke i praktike: Sbornik nauchnyh statej Nauchnoprakticheskoj konferencii studentov i aspirantov s mezhdunarodnym uchastiem (29-31 oktyabrya 2014 goda), s. 127-131.

Paper sent to revision: 26.07.2017.

Paper ready for publication: 17.08.2017. 